\title{
Standardized research protocols enable transdisciplinary research of climate variation impacts in corn production systems
}

\author{
E.J. Kladivko, M.J. Helmers, L.J. Abendroth, D. Herzmann, R. Lal, M.J. Castellano, D.S. Mueller, \\ J.E. Sawyer, R.P. Anex, R.W. Arritt, B. Basso, J.V. Bonta, L.C. Bowling, R.M. Cruse, N.R. Fausey, J.R. \\ Frankenberger, P.W. Gassman, A.J. Gassmann, C.L. Kling, A. Kravchenko, J.G. Lauer, F.E. Miguez, \\ E.D. Nafziger, N. Nkongolo, M. O'Neal, L.B. Owens, P.R. Owens, P. Scharf, M.J. Shipitalo, J.S. \\ Strock, and M.B. Villamil
}

\begin{abstract}
The important questions about agriculture, climate, and sustainability have become increasingly complex and require a coordinated, multifaceted approach for developing new knowledge and understanding. A multistate, transdisciplinary project was begun in 2011 to study the potential for both mitigation and adaptation of corn-based cropping systems to climate variations. The team is measuring the baseline as well as change of the system's carbon $(\mathrm{C})$, nitrogen $(\mathrm{N})$, and water footprints, crop productivity, and pest pressure in response to existing and novel production practices. Nine states and 11 institutions are participating in the project, necessitating a well thought out approach to coordinating field data collection procedures at 35 research sites. In addition, the collected data must be brought together in a way that can be stored and used by persons not originally involved in the data collection, necessitating robust procedures for linking metadata with the data and clearly delineated rules for use and publication of data from the overall project. In order to improve the ability to compare data across sites and begin to make inferences about soil and cropping system responses to climate across the region, detailed research protocols were developed to standardize the types of measurements taken and the specific details such as depth, time, method, numbers of samples, and minimum data set required from each site. This process required significant time, debate, and commitment of all the investigators involved with field data collection and was also informed by the data needed to run the simulation models and life cycle analyses. Although individual research teams are collecting additional measurements beyond those stated in the standardized protocols, the written protocols are used by the team for the base measurements to be compared across the region. A centralized database was constructed to meet the needs of current researchers on this project as well as for future use for data synthesis and modeling for agricultural, ecosystem, and climate sciences.
\end{abstract}

Key words: corn systems_climate—database—-research methods—-soil measurements

Stewardship of our agricultural resource base is crucial to the long-term sustainability of human civilizations. Soil, water, and air quality are essential components of a thriving agriculture and much research has been conducted over the decades to maintain and improve the quality of those basic resources. As the connections between agriculture, ecosystems, and climate have become more apparent in recent times, research projects have become larger, encompassing multiple disciplines and contributors across the nation and world. These projects produce large amounts of data that need to be available to the project team as well as other scientists for purposes of testing hypotheses, synthesizing data, and developing and using models for prediction. In addition, many excellent smaller scale projects from previous decades have data that are not readily available but would be useful for data synthesis and model testing. Various forms of research networks and databases have been developed to begin to meet the needs for greater data availability.

The USDA issued a Request for Applications for large, integrated projects on corn (Zea mays L.) cropping systems and climate in 2010 through the National Institute for Food and Agriculture (NIFA). The Request for Applications included specific language on establishing a regional network; developing standardized methodologies for evaluating carbon (C), nitrogen $(\mathrm{N})$, and water footprints; performing baseline monitoring; evaluating novel cropping systems; and performing comprehensive life cycle analyses of these systems. The Climate and Corn-based Cropping Systems Coordinated Agricultural Project (CSCAP) led by Lois Wright Morton at Iowa State University in Ames, Iowa, was selected to receive funding from this program. One of the first tasks of the new team was to agree upon the detailed field research protocols that would be used across all research sites. Research sites included treatments that were common management practices across the Midwest as well as novel or practices expected to allow greater sustainability of corn-based systems to a changing climate, including no-till management, $\mathrm{N}$ sensors for fertilizer rate management, drainage water management, extended crop rotations, and integration of cover crops into corn-soybean (Glycine max L.) rotations. The task of developing protocols was not a trivial matter. There are many acceptable standard procedures for measuring soil and crop parameters,

Eileen J. Kladivko is a professor in the Department of Agronomy at Purdue University in West Lafayette, Indiana. Matthew J. Helmers is an associate professor in the Department of Agriculture and Biosystems Engineering at lowa State University in Ames, lowa. Lori J. Abendroth is the project manager for Climate and Corn-based Cropping Systems Coordinated Agricultural Project (CAP) at lowa State University in Ames, lowa. Daryl Herzmann is an assistant scientist in the Department of Agronomy at lowa State University in Ames, lowa. Rattan Lal is a professor in the School of Environmental and Natural Resources at The Ohio State University in Columbus, Ohio. Michael J. Castellano is an assistant professor in the Department of Agronomy at lowa State University in Ames, lowa. Daren S. Mueller is an assistant professor in the Department of Plant Pathology and Microbiology at lowa State University in Ames, lowa. John E. Sawyer is a professor in the Department of Agronomy at lowa State University in Ames, lowa. Robert P. Anex Jr. is a professor in the Department of Agriculture and Biosystems Engineering at the University of Wisconsin in Madison, Wisconsin. Raymond W. Arritt is a professor in the Department of Agron-

Continued next page 
omy at lowa State University in Ames, lowa. Bruno Basso is an associate professor in the Department of Geological Sciences and W.K. Kellogg Biological Station at Michigan State University in East Lansing, Michigan. James V. Bonta is a research hydraulic engineer with the USDA Agricultural Research Service (ARS) National Sedimentation Lab in Oxford, Mississippi. Laura C. Bowling is an associate professor in the Department of Agronomy at Purdue University in West Lafayette, Indiana. Richard M. Cruse is a professor and director of the lowa Water Center in Department of Agronomy at lowa State University in Ames, lowa. Norman R. Fausey is a research science leader and supervisory soil scientist with the USDA ARS Soil Drainage Research Unit in Columbus, Ohio. Jane R. Frankenberger is a professor in the Department of Agricultural and Biological Engineering at Purdue University in West Lafayette, Indiana. Philip W. Gassman is an associate scientist at the Center for Agricultural and Rural Development (CARD) at lowa State University in Ames, lowa. Aaron J. Gassmann is an associate professor in the Department of Entomology at lowa State University in Ames, lowa. Catherine L. Kling is a professor at CARD and the Department of Economics at lowa State University in Ames, lowa. Alexandra Kravchenko is an associate professor in the Department of Crop and Soil Sciences at Michigan State University in East Lansing, Michigan. Joseph G. Lauer is a professor in the Department of Agronomy at the University of Wisconsin in Madison, Wisconsin. Fernando E. Miguez is an assistant professor in the Department of Agronomy at lowa State University in Ames, lowa. Emerson D. Nafziger is a professor in the Department of Crop Sciences at the University of Illinois in Urbana, Illinois. Nsalambi Nkongolo is a professor and GIS lab manager in the Department of Agriculture and Environment at Lincoln University in Jefferson City, Missouri. Matthew O'Neal is an associate professor in the Department of Entomology at lowa State University in Ames, lowa. Lloyd B. Owens is a retired soil scientist from the USDA ARS North Appalachian Experimental Watershed Laboratory in Coshocton, Ohio. Phillip R. Owens is an associate professor in the Department of Agronomy at Purdue University in West Lafayette, Indiana. Peter Scharf is a professor in the Department of Plant Sciences at the University of Missouri in Columbia, Missouri. Martin J. Shipitalo is a soil scientist with the USDA ARS Soil, Water, and Air Resources Research Unit in Ames, lowa. Jeffrey S. Strock is a professor in the Department of Soil, Water and Climate at the University of Minnesota in Lamberton, Minnesota. Maria B. Villamil is an assistant professor in the Department of Crop Sciences at the University of Illinois in Urbana, Illinois. but it was important for the project to establish uniform procedures so the data would be comparable. The intent is to have data available and shared with field researchers across the project, scientists performing data synthesis, modeling and life cycle analyses, and eventually with other researchers not involved directly with this project, and thus a set of standard procedures was important. This paper first outlines the process by which the group came to consensus on the standardized protocols, and then it discusses the protocols and the rationale and reasoning for each of those choices. This paper may also serve as a standard reference for other researchers and the agricultural community as a whole when conducting similar research; employing identical methodologies would allow data merging, extrapolation, and synthesis across time and space that is simply not currently possible in much of agricultural research because of different sampling procedures used.

\section{Materials and Methods}

The process of establishing research protocols occurred over the course of about a year, starting with the stage of proposal preparation and finishing about the time of the first field season measurements in spring of 2011. Proposal preparation began with one face-to-face meeting and subsequent conference calls and email discussions. The basic plan for soil, crop, and water sampling of the field treatment sites was established during this time, with the main parameters to measure and the generalized approach and methodology detailed. The many details of methodology were not yet fixed at that point in time. Upon notification that the project was selected for funding, planning of many details began in earnest. The scientists involved in the field experimentation as well as those involved with modeling and life cycle analysis had many discussions over the next four months and beyond. The proposal had articulated six main objectives and identified a leadership group for each of the objectives. The discussions were led by this leadership group for the field experimentation objectives and referred to as objectives 1 and 2 .

As can be imagined, trying to build consensus among about 30 principal investigators concerning every detail of field measurement protocols was quite a challenge. The scientists each had their own disciplinary expertise, ranging across agronomy, soil fertility, soil physics, hydrology, engineering, soil biology, cropping systems, greenhouse gasses, integrated pest management, and other related areas. Details that one scientist might consider inconsequential may be very important for another scientist and be critical for data quality and the usefulness of the data for future purposes (Boone et al. 1999). When possible, the group considered what other large networks had used for some of the protocols, such as depths for soil sampling (long term ecological research [LTER]) (Boone et al. 1999) and greenhouse gas measurements (GRACEnet) (Follett 2010).

Discussions among all principal investigators with field responsibilities occurred at an all-team meeting the month before the project began. Objective team leaders had phone discussions before that meeting to outline their understanding of the measurements proposed and the detailed decisions that needed to be made by the group. The objective team leaders led the discussion, going point by point through each of the parameters until consensus was reached or the need for further information was apparent. The group did not get through all the measurements during the in-person meeting and then had follow up conference calls to complete the discussion of each measurement. Written protocols were circulated and revised with further discussions. Major efforts were made to get input from all investigators in the discussions and decisions regarding methods.

The standardized protocols included soil and crop (agronomic) measurements for all sites, water measurements for those sites studying drainage, and greenhouse gas flux measurements at the soil surface for those sites monitoring gas fluxes. Discussion began from the point of what the group had stated in the proposal, and details and modifications were made from that starting point. Numerous criteria were explicitly considered in the discussions as details were debated. For soils this included what the minimum parameters for calculation of a Soil Quality Index (SQI) would be, as this index was discussed in the grant proposal. The group considered requests from the data synthesis and modeling objective team members (objective 3) for what they would consider a minimum data set for their needs. Standardized protocols incorporated what was reasonable and doable by all of the 
teams, with different areas of expertise. The depth, timing, frequency, and methodology of various soil measurements probably generated the most discussion. The group tried to strike a balance between a comprehensive, "level III, most intensive" and a "level I, least intensive" sampling intensity, as described for LTER sites (Boone et al. 1999). Some of the decisions were based on what was considered likely to change in the 3- to 5-year time period of the project. Although the 5 -year timeframe of this project is longer than many grant-funded agricultural projects, it is well known that soil organic $\mathrm{C}$ takes many years to show measurable differences as a result of a change in management. The group struggled to balance the requests for baseline monitoring of systems and monitoring of change resulting from new systems, within the 5-year period of the project, for some of the parameters that would not likely change. Other more dynamic measurements that change quickly with new management practices were integrated with more slowlychanging parameters to be able to show the direction and potential magnitude of change.

To take advantage of the extensive expertise of the research team, some measurements were detailed as optional measurements. These allowed for more intensive measurements of some soil or crop parameters (e.g., penetration resistance, infiltration, soil organic $\mathrm{C}$ fractions) on some of the sites and inclusion of the data in the database. The general criteria for such inclusion were that at least three of the research sites would be making those measurements. Other sites continued to make other additional measurements appropriate to their research specialty that were not to be added to the database. The research network included previously established sites, such as historical rotation plots, as well as newly installed plots to meet the needs of the CSCAP; the protocols helped to bridge across these and emphasize areas of commonality via collecting identical measurements.

The standardized protocols served as the conceptual framework for the team's central database which is a combined model using a traditional relational database and cloud computing (Herzmann et al. 2014). The database was not in existence before funding was awarded, which meant direct tailoring to team needs was taken into consideration from the start and built to allow high flexibility and transparency. The standardized protocols served as the starting point for the development and characterization of the sites with "required" or "optional" applied to each measurement across sites, treatments, and plots to derive a series of matrices that defined each site. Every research site is characterized by experimental treatments, data types collected, and supporting metadata. Details pertaining to field management operations and other metadata were expanded substantially beyond that originally written to provide over 100 management parameters that are crucial for understanding the measured data collected from the standardized protocols and facilitate appropriate synthesis and modeling of it.

\section{Results and Discussion}

Soils. Table 1 shows the starting point for discussions related to soil measurements. It documents the soil parameter, general measurement method, ways the data are used in data synthesis, and a reference for the general procedure. It also indicates whether the parameter is generally needed for estimation of a SQI. Selected sites in the field research network are measuring all parameters in this table, while most sites are measuring a subset of measurements deemed as "required," as detailed below and in table 2 . The rationale for each measurement and the justification for the decisions regarding depth, timing, frequency, and methodology for the major measurements in table 2 are discussed below.

Depth of soil sampling was decided to be 0 to $10 \mathrm{~cm}$ (0 to $3.9 \mathrm{in}$ ), 10 to $20 \mathrm{~cm} \mathrm{(3.9} \mathrm{to}$ $7.9 \mathrm{in}), 20$ to $40 \mathrm{~cm}$ (7.9 to $15.7 \mathrm{in})$, and 40 to $60 \mathrm{~cm}$ (15.7 to $23.6 \mathrm{in})$ except for soil nitrate $\left(\mathrm{NO}_{3}-\mathrm{N}\right)$. The choice of 0 to $10 \mathrm{~cm}$ (0 to 3.9 in) and 10 to $20 \mathrm{~cm}$ (3.9 to $7.9 \mathrm{in})$ rather than 0 to $15 \mathrm{~cm}$ (0 to $5.9 \mathrm{in}$ ) was intensely debated, but in the end our decision was consistent with the recommendation of Boone et al. (1999) who stated that samples taken from 0 to $15 \mathrm{~cm}$ (0 to 5.9 in) are discouraged because they often do not encompass the full plow depth in soils. In our case, there were sites using no-till and other sites using chisel plow or other tillage implements. Most modern full width and depth tillage implements operate closer to $20 \mathrm{~cm}$ (7.9 in) than to $15 \mathrm{~cm}$ (5.9 in), and thus $20 \mathrm{~cm}$ (7.9 in) is more appropriate. For sites using no-till, we are often interested in the potential stratification of $\mathrm{C}$ and nutrients within the topsoil, therefore splitting the samples into 0 to 10 (0 to 3.9 in) and 10 to 20 $\mathrm{cm}$ (3.9 to $7.9 \mathrm{in})$ increments was appropriate.
The decision to sample the soil profile to $60 \mathrm{~cm}$ (23.6 in) was a compromise between taking only three depth increments, to $40 \mathrm{~cm}$ (15.7 in) total, and taking more depth increments up to $100 \mathrm{~cm}$ (39.3 in), which would be desirable for long-term studies. The 5-year project timeframe would not be long enough to expect any changes in $\mathrm{C}$ and $\mathrm{N}$ at depths below $60 \mathrm{~cm}$ (23.6 in), and in many cases not even at depths below $20 \mathrm{~cm}$ (7.9 in) (BlancoCanqui and Schlegel 2013). Sampling to 100 $\mathrm{cm}$ (39.3 in) depth is also considerably more difficult in many of the soils in this regionfor the types of samples to be collected-so the decision was to focus efforts on depths and properties that were expected to change. Going to a depth of $60 \mathrm{~cm}$ (23.6 in) allows for the possibility of a deeper assessment of changes in $\mathrm{C}$ stocks if the project continues for longer than the original 5-year period. The combined depth increments chosen put our sampling intensity close to the level II, more intensive sampling scheme discussed for LTER projects by Boone et al. (1999).

Most baseline soil measurements were to be sampled in years one, three, and five of the project. Although it is expected that some measurements will not have changed in the first two years, it seemed important to document directions of change before the end of the project. For some properties, the year three measurements were to be made on the top two depths only, again to focus efforts to depths where changes may be detected more quickly.

Bulk Density. Bulk density is a basic soil property needed to understand soil quality, water flow, root development, and many other processes. It is also needed to convert $\mathrm{C}$ and $\mathrm{N}$ values measured as concentrations to a volume basis for calculating $\mathrm{C}$ and $\mathrm{N}$ stocks in the soil profile. It was also expected to change within the timeframe of this project, especially in the first two depths. Bulk density was to be sampled in spring when soil is moist and clays are still fully hydrated after winter rewetting. Since bulk density samples were also to be used for water retention measurements and intended to reflect water availability to plants early and midseason, it was decided that samples taken in spring were more appropriate than in fall after harvest when the soil is dry and usually at a higher bulk density than in spring. The exact timing of spring samples was to be decided by individual researchers based on both scientific issues (tillage system timing, if any) and practical issues (weather and soil 


\section{Table 1}

Assessing management impacts on soil quality and soil carbon (C) pool fluxes.

\begin{tabular}{|c|c|c|c|c|}
\hline Parameter & $\begin{array}{l}\text { Soil } \\
\text { Quality } \\
\text { Index }\end{array}$ & Method & Data synthesis & References \\
\hline \multicolumn{5}{|l|}{ Physical properties } \\
\hline Soil structure & & Wet sieving & $\begin{array}{c}\text { Mean weight diameter and } \\
\text { water stable aggregation }\end{array}$ & Nimmo and Perkins (2002) \\
\hline Water retention curves & $\mathrm{x}$ & $\begin{array}{l}\text { Pressure plate, } \\
\text { tension table }\end{array}$ & $\begin{array}{l}\text { Available water capacity, } \\
\text { pore size distribution }\end{array}$ & Dane and Hopmans (2002) \\
\hline Soil temperature & & $\begin{array}{l}\text { Thermocouple } \\
(5 \mathrm{~cm} \text { depth) }\end{array}$ & Degree days & Mcinnes (2002) \\
\hline Infiltration rate & & Ring infiltrometer & Transmissivity, sorptivity & Reynolds et al. (2002) \\
\hline Soil moisture & & Dielectric permittivity & Volumetric water content & Topp and Ferre' (2002) \\
\hline Particle size & & Hydrometer & Texture, uniformity coefficient & Gee and Or (2002) \\
\hline Organic matter characterization & & Fractionation & Labile fraction & Swift (1996); Denef et al. (2009) \\
\hline Total and organic nitrogen $(\mathrm{N})$ & $x$ & Dry combustion & $\mathrm{N}$ pool, $\mathrm{N}$ fluxes & Bremner (1996); Stevenson (1996) \\
\hline $\begin{array}{l}\text { Cation exchange capacity and } \\
\text { exchangeable cations }\end{array}$ & $x$ & Ammonium acetate & Base saturation & Sumner and Miller (1996) \\
\hline Nitrate concentration & & Colorimetry & Nitrous oxide $\left(\mathrm{N}_{2} \mathrm{O}\right)$ emission & Mulvany (1996) \\
\hline \multicolumn{5}{|l|}{ Biological properties } \\
\hline $\begin{array}{l}\text { Fractionation of soil } \\
\text { organic matter }\end{array}$ & & $\begin{array}{l}\text { Density method, } \\
\text { colorimetrics }\end{array}$ & Humic components & $\begin{array}{l}\text { Stevenson (1994); Islam and } \\
\text { Weil (1998) }\end{array}$ \\
\hline Particulate organic matter & & Flotation & Mineralizable soil organic matter & Cambardella and Elliot (1992) \\
\hline
\end{tabular}

conditions), and could be before planting or within a month after planting and soil settling after several rainfalls. Samples were to be taken in the quarter-row position (onefourth of the distance from one corn row to the next) to avoid the row and fertilizer bands, where appropriate. Hand core samples were to be used for the top two depths, while the deeper two depths could use either hand cores or hydraulic probe cores (hydraulic probe cores may not be sufficiently precise for looser surface depths, plus hand cores are needed for water retention measurement).

Soil Organic Carbon, Total Nitrogen, $p H$, and Cation Exchange Capacity. Soil Organic C, total N, pH, and cation exchange capacity (CEC) were to be determined on samples from all four depths in years one, three, and five. The major focus of the project is on $\mathrm{C}, \mathrm{N}$, and water footprints, and thus these soil samples are essential for the analysis, even if the values do not show measurable changes over the first few years. A minimum of 12 standard soil probes per composite sample per plot and depth were required. Alternatively, if a group was taking separate samples for bulk density and for water retention, then a minimum of three samples composited from bulk density cores could be used instead. Samples were to be air-dried and crushed to pass a $2 \mathrm{~mm}$ (0.08 in) sieve, with any gravel retained on the $2 \mathrm{~mm}(0.08$ in) sieve weighed to determine the skeletal fraction of the whole sample. Subsamples of the $<2 \mathrm{~mm}$ (0.08 in) fraction were to be ball milled or finely ground to pass a $250 \mu$ sieve for $\mathrm{C}$ and $\mathrm{N}$ analysis. Both $\mathrm{C}$ and $\mathrm{N}$ were to be determined by dry combustion after checking for calcareous conditions and accounting for inorganic $\mathrm{C}$, if it was present.
The $\mathrm{pH}$ was to be measured with a standard 1:1, soil:water ratio. Although CEC is best measured with ammonium acetate as a summation of all cations, the group decided that the summation of major cations plus hydrogen $(\mathrm{H})$ estimation from buffer $\mathrm{pH}$ as performed by most commercial soil testing labs, would be adequate for the purposes of this project. However, for soil sample depths with free carbonates, the more expensive analysis would be needed.

Soil Texture. Soil texture is a basic soil property required for any soil study and interpretation. Soil texture was to be measured on every plot, once at the beginning of the study using the hydrometer method. In addition, it was highly recommended to obtain a complete soil taxonomic description of the site from pedologists from the land- 
Table 2

Standardized research protocols for field measurements of soil, water, plant, and weather parameters for the Climate and Corn-based Cropping Systems Coordinated Agricultural Project (CSCAP).

\section{Prioritized measurements}

1. Bulk density (BD) - Minimum three replicate cores per depth per plot
a. 0 to $10 \mathrm{~cm}$
b. 10 to $20 \mathrm{~cm}$
c. 20 to $40 \mathrm{~cm}$
d. 40 to $60 \mathrm{~cm}$

Rationale:

- Convert gravimetric $\mathrm{C}, \mathrm{N}$ to volumetric $\mathrm{C}, \mathrm{N}$, (for total $\mathrm{C}, \mathrm{N}$ mass per depth and per soil profile)

- An indicator of soil quality (by itself)

- Needed for soil quality index

- Needed for models

- Expected to change with time in treatments, especially first two depths
Details (sampling, sample preparation and laboratory analysis)

Minimum sample in years one, three, and five. May limit samples in year three to 0 to 10 and 10 to $20 \mathrm{~cm}$ depths, if necessary.

Specific procedures depend on whether same samples will be used for carbon (C), nitrogen (N), and/or water retention. Recommend that these same samples be used for water retention.

Sampling:

- Use core method (hand system or truck/tractor system) with a minimum of $5 \mathrm{~cm}$ diameter core tube.

- Use hand core on top two depth (0 to $10 \mathrm{~cm}, 10$ to $20 \mathrm{~cm}$ ) on all plots (including no-till). Hand cores $(6 \mathrm{~cm}$ tall) should be taken in approximate center of each depth interval. Recommended to use these same hand-core samples for water retention measurements (see below).

- Use either hand core or hydraulic probe for 20 to $40 \mathrm{~cm}$ and 40 to $60 \mathrm{~cm}$ depths.

- Minimum of three cores at each depth on each plot. Take more samples on large plots (to represent the plot).

- Take samples in spring. This can either be before spring tillage or planting, or after planting, depending on scientific issues (your particular tillage situation) and practical ones (weather and soil conditions). After planting, suggest taking samples 20 to 30 days after planting to allow for soil settling but to still be in early season when soil clays are fully hydrated. (If deeper depths are still too wet for sampling at that time, then take the shallow depth samples $(0$ to $10 \mathrm{~cm}$ and 10 to $20 \mathrm{~cm}$ ) at 20 to 30 days, and then go back later ( 4 to 8 weeks) with hand cores at deeper depths). Strive to take samples at same relative time each year that is sampled (i.e., always before spring field work or always after planting).

- Take samples from the quarter-row position (out of wheel tracks and fertilizer application zone) for corn

- Take samples between drilled rows from soybeans.

- Organic/manure experiments need to coordinate among themselves on soil sampling times.

Minimum sample in years one, three, and five, all 4 depths.

SOC, Total N, pH, CEC (CEC in year 3 could be limited to 0 to $10 \mathrm{~cm}$ and 10 to $20 \mathrm{~cm}$, if needed, but all 4 depths should be run for $\mathrm{C}, \mathrm{N}, \mathrm{pH}$ ).

Sampling:

- If enough soil is available to measure all parameters with bulk density samples, no push probes would be needed. This is unlikely because you will likely use your BD samples for water retention also.

o Do not oven dry samples before chemical analysis.

o Make sure to weigh subsample for air-dry to oven-dry conversion, or moist to oven-dry conversion depending on how samples are managed.

- If $B D$ samples are being used for water retention, then chemical samples are from standard push probe samplings. Minimum of 12 hand push-probe samples composited per depth per plot.

o Watch for compaction on surface

o These will be composited by depth

o These should be taken in same row positions as the bulk density samples (since will use $\mathrm{BD}$ to convert gravimetric to volumetric $\mathrm{C}, \mathrm{N}$, etc.).

- Air dry the samples.

- Crush/grind to pass through $2 \mathrm{~mm}$ sieve. Weigh the gravel retained on the $2 \mathrm{~mm}$ sieve, and the soil (fine fraction) that passes through the $2 \mathrm{~mm}$ sieve, to determine skeletal fraction of whole sample.

- Take subsample of the fine fraction, and ball mill or grind to pass through a 250 um sieve, for $\mathrm{C}$ and $\mathrm{N}$ analyses (i.e., must be finely ground for proper measurement).

- SOC analysis: check for calcareous conditions; may have to account for inorganic C. Use dry combustion. 


\section{Table 2 continued}

\section{Prioritized measurements}

- $\mathrm{pH}$

o General soil characterization

o Needed for soil quality index

o Needed for models

o Needed for agronomic management

- $\mathrm{CEC}$

o General soil characterization

o Needed for soil quality index

- May change as soil $\mathrm{C}$ changes

3. Texture analysis
a. 0 to $10 \mathrm{~cm}$
b. 10 to $20 \mathrm{~cm}$
c. 20 to $40 \mathrm{~cm}$
d. 40 to $60 \mathrm{~cm}$

Rationale:

- General soil characterization

- Needed for soil quality index

- Needed for models

- Not likely to change unless severe erosion

- But differences across plot area, especially if large plots, can affect water relations and confound other effects, if not known. Thus the decision to measure every plot in year one.

4. Standard soil fertility routine analysis Rationale:

- Good agronomic management

- Needed for some models for topsoil layer(s)

5. Water Retention (use BD cores)
a. 0 to $10 \mathrm{~cm}$ (required)
b. 10 to $20 \mathrm{~cm}$ (required)
c. 20 to $40 \mathrm{~cm}$ (encouraged)
d. 40 to $60 \mathrm{~cm}$ (encouraged)

Rationale:

- An indicator of soil quality (by itself)

- Wet end needed for interpretation of GHG measurements

- Needed for soil quality index

- Needed for models (field capacity and wilting point)

- Expected to change with time in treatments, especially first two depths
Details - sampling, sample preparation, and laboratory analysis

- $\mathrm{pH}:$ 1:1 soil:water $\mathrm{pH}$.

- CEC: Summation of all cations is best, but we decided that the standard commercial lab procedure of estimating by summing major cations plus $\mathrm{H}$ from buffer $\mathrm{pH}$ was adequate. If any of the soil depths have free carbonates, however, the more expensive test will need to be done.

Note: Sampling for texture in year one can be combined with push probe samples for $\mathrm{C}, \mathrm{N}, \mathrm{pH}, \mathrm{CEC}$, as described above.

Year one only, but it should be done on every plot and all 4 depths. Hydrometer method is sufficient. Also need to determine skeletal fraction (i.e., gravel) - see details on sample prep under item 2 (soil $\mathrm{C}$ and $\mathrm{N}$ )

In addition to texture by depth and plot, it would be good to get complete soil description from state NRCS soil scientist or the pedologist at your university, and should go deeper than the $60 \mathrm{~cm}$ of sampling for all other soil samples (i.e., depth of soil profile or rooting zone).

Group decided this was not part of the required data for Soil Quality Index, and that each state should do their standard soil fertility test protocols for good agronomic management. Details left to the discretion of individual researchers (i.e., depths of sampling, particular extractants for $P$ and $\mathrm{K}$, buffer $\mathrm{pH}$, etc.). Description of methods (i.e., extractants) should be included in metadata for each site.

Sampling:

- Sample in years one, three, and five. See details for bulk density.

- Water Retention $(0,-0.05,-0.1,-0.33,-15$ bar, with additional freely drained for surface samples for greenhouse gas studies)

- May use bulk density samples for the saturated, freely drained, $-0.05,-0.1,-0.33$ bar and crushed soil for the -15 bar test. Required on 0 to $10 \mathrm{~cm}$ and 10 to $20 \mathrm{~cm}$ depths. (Therefore are sampled in spring, as detailed under bulk density explanations)

- "Freely drained" is of importance to greenhouse gas emissions. Do this for 0 to $10 \mathrm{~cm}$ depth soils only. Measure by saturating cores as usual for water retention measurement, then weigh saturated cores, then allow to freely drain (no suction) for 2 hours (plastic film on top to minimize evaporation), weigh core again, and then proceed with 0.05 bar equilibration, 0.1 bar equilibration, and 0.33 bar equilibration. The "freely drained" will therefore have a water potential of $0 \mathrm{~cm}$ at the bottom and $-6 \mathrm{~cm}$ at the top (of a $6 \mathrm{~cm}$ tall core).

- Highly encouraged to measure water retention curves at all 4 depths. If necessary, however, can use a pedotransfer function on deeper soils (20 to $40 \mathrm{~cm}$ and 40 to $60 \mathrm{~cm}$ ), using data on $\mathrm{BD}$, texture, and organic C.

- Select appropriate plots for water retention if time/resources do not allow all to be completed.

o For example: select the corn year of a corn-soybean rotation to collect data in year one, three, and five.

- Optionally, measure more points for more complete water retention curve, especially for drainage plots. Perhaps $10,30,50,75 \mathrm{~cm}$ suction in addition to 0.1 bar $(100 \mathrm{~cm})$ and 0.33 and 15 bar.

Table 2 Continued 
6. Soil for insect analysis - (12 to 15 push probe samples, composited) 0 to $20 \mathrm{~cm}$ depth

7. Integrated pest management
Sampling:

- Minimum of 12 to 15 standard push-probe (0.75 in) samples ( 0 to $20 \mathrm{~cm}$ ) composited and air dried. Take at same time as the other soil samples.

Corn:

- Foliar disease was visually assessed as a percentage of total leaf area infected. Ten to 15 plants per plot were rated by properly identifying the foliar disease(s) and estimating the amount of diseased leaf tissue on the ear leaf and the second leaf above the ear leaf.

- Nine to 15 ears in each plot were rated for ear rots by identifying the specific ear rot and visually assessing the percentage of the total ear infected.

- Stalk rots were assessed on five consecutive plants in three rows using the push test $\left(30^{\circ}\right)$. Incidence of lodging and type of stalk rot also were recorded.

- Insect populations were assessed using sticky traps, pit fall traps, and sweep netting. Insects from traps are brought back to the lab and the number of common insect pests were identified and enumerated.

Soybean:

- Foliar disease was visually assessed as a percentage of total leaf area infected. Twenty to 25 leaves in the upper and lower canopy were rated in each plot by properly identifying the foliar disease(s) and estimating the amount of blighted leaf tissue on each leaf.

- Stem diseases such as white mold and sudden death syndrome were assessed at the plot level when present.

- Insect populations were assessed using sticky traps, pitfall traps, and sweep netting. Insects captured from traps were brought back to the lab and the common insect pests were identified and counted.

- When soybean aphids were present, it was determined if the threshold (250 aphids per plant and increasing) was exceeded by using the Speed Sampling technique (Hodgson et al.).

8. Greenhouse gas emissions Starting in 2012 for most sites.

Detailed protocols (lqbal et al. 2012).

9. Soil nitrate $\left(\mathrm{NO}_{3}\right)$ - cover crop sites Timing

- Fall - after cash crop harvest.

Soil $\mathrm{NO}_{3}$ - Drainage water management sites (fall sampling only)

- Spring - right before rye termination.

- Summer - presidedress $\mathrm{NO}_{3}-\mathrm{N}$ test (PSNT) timing.

Depths:

Soil $\mathrm{NO}_{3}-\mathrm{N}$ rate/sensor sites

- Fall $-90 \mathrm{~cm}$ deep in $30 \mathrm{~cm}$ increments.

- Spring $-60 \mathrm{~cm}$ deep in $30 \mathrm{~cm}$ increments.

- Summer (optional) $-60 \mathrm{~cm}$ deep in $30 \mathrm{~cm}$ increments.

10. Soil moisture (required tile drainage, cover crop; optional for others)

a. $10 \mathrm{~cm}$

b. $20 \mathrm{~cm}$

c. $40 \mathrm{~cm}$

d. $60 \mathrm{~cm}$

e. $100 \mathrm{~cm}$

Sampling:

- Decagon instruments as described in cover crop protocols, for 8 of the 16 plots. One logger with 5 sensors per plot (also measures soil temperature).

- Place in quarter-row position, as with other sample locations.

- Program to log moisture every five minutes (better for watching wetting fronts, etc., and still within the storage capacity of the logger).

- For drainage plots, place sensors at midplane between tiles, and at least two times the drain spacing width from the main drain. This is also where the water table well should be, if you have one. Located in the zone of field most affected by control structure.

- See Decagon website for helpful installation suggestions.

11. Water quality (tile drainage)

Measure drainage volume continuously.

Table 2 Continued 


\section{Table 2 continued}

\section{Prioritized measurements}

12. Plant (cash crop) samples

Rationale:

- Yield is obvious goal

- Above ground biomass for $\mathrm{C}$ and $\mathrm{N}$ inputs to system

- Needed for models

\section{Details (sampling, sample preparation, and laboratory analysis)}

Grain yield for all plots - your standard agronomic procedures.

Above ground biomass:

- Corn (required) - six random representative (don't sample if barren ears or double ears) corn plants per plot, sampled at physiological maturity (approximately black layer).

- With the six hand harvested plants:

o Shuck the ears and set aside.

o Weigh all biomass (ears not included) together, chop and subsample for moisture and $\mathrm{N}$ analysis.

o Dry the ears, and weigh all six ears together. Shell the ears, weigh the dry grain for yield calculation.

o Cobs do not need to be included in the $\mathrm{C}$ and $\mathrm{N}$ analysis. Standard values will be used.

o Use the relationship among grain, cob, and rest of vegetative matter to upscale from your grain yield for whole plot, to get vegetative biomass and $\mathrm{C}$ and $\mathrm{N}$ content for whole plot.

- Soybeans (optional, to do on a few plots per year to account for variations with variety and year) - after leaf drop, cut a length of row (perhaps $3 \mathrm{ft}$ ) for whole plant biomass (includes stem plus beans) per area. After grain yield is obtained in your usual way, subtract grain biomass per area from whole plant biomass per area, to get vegetative biomass per area.

- Wheat - (optional) similar idea to soybeans.

$\mathrm{N}$ of grain and above-ground biomass:

- A few representative samples required each year, to account for differences in years, hybrids/ varieties, etc. (Those doing $\mathrm{N}$ studies should do more, to represent the $\mathrm{N}$ treatments). Analyze total $\mathrm{N}$ for grain and each plant part sampled (except cob). A standard value for $\mathrm{C}$ will be used for each plant part.

- A separate file posted on database gives even greater details on procedures.

13. Plant populations Plant populations (corn) should be harvested plant populations (i.e., determined right before or at harvest time).

Methods can vary, but would include counting either the entire plot harvest length (on small plots), or a minimum of four rows of $17.4 \mathrm{ft}\left(1 / 1000^{\text {th }}\right.$ of acre if on $30 \mathrm{in}$ rows) on larger plots. The counted length can be greater (i.e., $20 \mathrm{ft}$ or $40 \mathrm{ft}$ ), if desired, but be sure to record the length used.

14. Agronomic management metadata
Complete the metadata worksheet developed for CSCAP research sites, it includes data types such as:

- Planting dates, harvest dates

- Plant populations

- Hybrid/variety used

- Tillage - timing, implements used and depth for each

- Residue management - e.g. amount removed vs. retained, if applicable; whether any processing (e.g., chopping)

- Fertilization - timing, rate, type, and application method

- Liming - timing, rate, and type

- Pest management data

- Organic amendments - timing, rate, type (e.g., FYM, dairy slurry, etc.) application method, $\mathrm{C}$ and $\mathrm{N}$ content and dry matter percentage

- Irrigation - timing, rate, and type

- Burning (if applicable) - when; estimate of biomass combusted, if possible

- Manure application amounts - simple measurement (e.g., eight truckloads, each approximately five tons)

15. Plant (cover crop) samples
Sample rye in late fall before freeze, if growth of more than a few inches.

Sample above ground biomass right before spraying in spring.

Sampling:

- Use $0.5 \times 0.5 \mathrm{~m}$ frames $\left(0.25 \mathrm{~m}^{2}\right)$. Choose minimum of two representative locations per plot, cut rye by hand (hand grass clippers), dry, then weigh dry material. Grind and subsample for total $\mathrm{N}$ analysis (will use standard values for $\mathrm{C}$ ). Calculate dry matter production and $\mathrm{N}$ in top growth per area.

Table 2 Continued 
16. Weather data

17. Infiltration and field capacity (optional)

19. Soil C pools, fractions (optional)

20. Penetration resistance (optional)

21. Earthworm activity (optional)
Daily precipitation on site.

Other standard weather variables on-site when possible, or available from nearby station (daily max and min temp, radiation, humidity, and wind speed).

Can use simple recording rainguage (tipping bucket with integrated logger, like Hobo, Onset, others), download weekly and clean out avian guano each time.

Double-ring infiltrometer, for three hours. Then cover ring with plastic, return 24 hours later and take soil sample with depth in center ring, for measure of redistributed water and a field estimate of field capacity.

Or some may use sprinkling infiltrometer.

Yoder wet-sieving type of method. Calculate Mean weight diameter and water stable aggregates. Sample soil while moist and friable, gently push through $8 \mathrm{~mm}$ screen, allow to air dry. If samples will not be run within 4 to 6 weeks of drying, then keep samples in cold room until analysis.

These analyses likely need samples that are NOT crushed to pass the $2 \mathrm{~mm}$ sieve. For those interested, another set of samples might be taken, air-dried, but NOT further processed. Current suggestion is to do $\mathrm{C}, \mathrm{N}$ analyses on aggregate size fractions from a wet-sieving procedure. Thus samples would be taken as described for aggregation, and stored for later analyses.

Optional measurement years one and five. Need to collect soil moisture data also. Minimum of 8 penetrations per plot. Suggested readings every $2.5 \mathrm{~cm}$ with digital recording penetrometer, to $60 \mathrm{~cm}$ depth. Should also be measured about the same time as other soil sampling in early season.

Optional earthworm counts in years one and five. Should be done in early spring, when populations are most active. Includes counting/observing middens for deep burrowers and mustard extraction for estimation of both shallow and deep species. grant university or the Natural Resources Conservation Service (NRCS).

Standard Soil Fertility Testing. Standard soil fertility testing was left to the discretion of the individual researchers in each state, to use their standard procedures including depths of sampling, extractants for nutrients, etc. A description of the procedures used were to be included in the metadata for each site.

Water Retention Curves. Water retention curves were considered essential for calculation of a soil quality index and as a measure that would be expected to change over a several year timeframe with changes in management systems. They are also required inputs in many ecosystem models. Because of the number of samples involved, the time required to run the curves, and the lack of appropriate equipment at some of the sites, the water retention curves were required for the top two depths and optional for the bottom two depths. Samples were to be run on the intact cores for a series of steps including saturation, -0.05 bar (aeration porosity, or large pores), and -0.10 and -0.33 bar (two different estimates of field capacity). In addition, an extra measurement point was inserted on the wet end of the water retention curve, called "freely drained," in which the cores were equilibrated under free drainage, without any applied tension. This measurement was made for the surface soil samples, as an index to relate to greenhouse gas measurements under wet field conditions. The wilting point ( $-15 \mathrm{bar})$ was to be run on $<2 \mathrm{~mm}$ (0.08 in) crushed soil.

Soil was collected in year one for an analysis of soil insect pests, similar in manner to typical soil fertility testing. A minimum of 12 standard soil probes to a depth of $20 \mathrm{~cm}$ (7.9 in) were composited and analyzed for insect pests at one central location. Funding was limited in the proposal for integrated pest management (IPM) measurements although IPM is expected to be a significant factor in the adaptability of Midwest cropping systems to a changing climate. Additional funding was received by the United Soybean Board and allowed for the addition of 12 faculty and 3 graduate students. The combined IPM team developed standardized protocols for use across the research area. Data being collected includes soil-borne disease incidence, foliar disease incidence and severity, insect populations, and weed populations. The value of collecting pest data to complement the larger project is two-fold. First, if any damaging pests are present at a particular location, the subsequent impacts on yield may be taken into account in crop models. Second, if any pest trends do occur in the multistate scouting, these may trigger specific modeling efforts. However, because the plots are set up to address nonpest related research, the pest data collected by the IPM team will most likely be used for identifying possible pest outbreaks at each location. Diseases and insect pests were assessed visually in corn and soybean fields. Prior to assessing damage in the field, scouts were trained using Severity Pro, which is a software program to train people on accurately assessing the percentage of leaves that are damaged (Nutter and Litwiller 1998). The IPM baseline measurements collected across sites are included in table 2 .

The remainder of the soil measurements were either required for some treatment systems and not others, or were considered optional. For example, soil moisture was required for the drainage water management sites and the cover crop sites, but not for the tillage sites, extended rotation sites, and $\mathrm{N}$ sensor sites. The field experimental sites included these five major groupings of management systems, but most institutions were conducting studies on only two or three of these five systems in the project.

Greenhouse Gas Fluxes. Greenhouse gas fluxes at the soil surface were to be measured at 10 sites that represent 7 states and 8 institutions. Measurements began in year one at sites where investigators had previous trace gas measurement experience. At all other sites, measurements began in year two. Methane $\left(\mathrm{CH}_{4}\right)$ and nitrous oxide $\left(\mathrm{N}_{2} \mathrm{O}\right)$ were the target gases. Carbon dioxide $\left(\mathrm{CO}_{2}\right)$ was not included because net fluxes of this gas at the soil surface do include $\mathrm{CO}_{2}$ uptake by plants and thus do not rep- 
resent the net ecosystem $\mathrm{CO}_{2}-\mathrm{C}$ exchange (Lovett et al. 2006; Parkin and Venterea 2010). Measurement protocols follow the USDA ARS GRACEnet (Greenhouse Gas Reduction through Agricultural Carbon Enhancement Network) protocols for chamber-based trace gas flux measurement (Parkin and Venterea 2010). Because not all sites had access to gas chromatography (GC), which is the most widely used method for $\mathrm{CH}_{4}$ and $\mathrm{N}_{2} \mathrm{O}$ analysis, five sites were to use photoacoustic infrared spectroscopy (PAS) for $\mathrm{N}_{2} \mathrm{O}$ measurement; although $\mathrm{CH}_{4}$ is not measured at sites using PAS, the global warming potential of maize-based agricultural systems is dominated by $\mathrm{N}_{2} \mathrm{O}$ (Linquist et al. 2012). Given the use of two different methods for $\mathrm{N}_{2} \mathrm{O}$ measurement, the comparability of $\mathrm{N}_{2} \mathrm{O}$ measurement at the soil surface with GC and PAS was evaluated and published in year one (Iqbal et. al 2013). The frequency of gas measurement at each site varies due to the large labor requirements associated with these measurements.

Soil Nitrate. Soil $\mathrm{NO}_{3}-\mathrm{N}$ is of particular interest to the systems using winter cover crops, drainage water management, and $\mathrm{N}$ sensing tools for optimal fertilizer $\mathrm{N}$ rate determinations. Sites with these three management systems were to take deep soil cores $(90 \mathrm{~cm}$ [35.4 in] depth, split into $30 \mathrm{~cm}$ [11.8 in] increments) in fall to characterize the soil profile after crop harvest and before the main winter leaching period. For the cover crop sites, the samples were to be taken in late fall, at the same time as the cover crop biomass was assessed to determine residual soil $\mathrm{NO}_{3}-\mathrm{N}$ status in the presence and absence of a cover crop. In spring, the cover crop sites were to be sampled to a $60 \mathrm{~cm}$ (23.6 in) depth, split into $30 \mathrm{~cm}$ (11.8 in) increments, at the same time as spring cover crop biomass determination, right before cover crop termination. This timing would reflect the $\mathrm{N}$ scavenged by the cover crop. Optional samples at presidedress $\mathrm{NO}_{3}-\mathrm{N}$ test (PSNT) timing were recommended for sites where sidedress $\mathrm{N}$ was part of the management system.

Soil Moisture. Soil moisture measurements were required for sites studying drainage water management and sites studying cover crops. The method selected was dielectric permittivity at depths of 10, 20,40, 60 , and $100 \mathrm{~cm}(3.9,7.9,15.7,23.6$, and 39.4 in). The particular sensors purchased also measured soil temperature (Decagon 5TM sensors). The sensors were programmed to take readings every five minutes for future use when looking at wetting fronts, heat penetration, or other dynamic processes. For many purposes a daily average soil water content and the maximum, minimum, and mean daily temperature would be sufficient.

For drainage water management studies, drainage flow was to be recorded continuously. Water samples were to be taken at least once per week from each plot for $\mathrm{NO}_{3}-\mathrm{N}$ analysis.

Other optional soil measurements were expected to be collected at a few research sites. These include infiltration using the double ring method, penetration resistance using a cone penetrometer, earthworm activity by counting middens and using a mustard extractant, aggregation by wet sieving, and soil $\mathrm{C}$ pools and fractions. See table 2 for details on procedures chosen for these extra analyses.

Agronomic data required of all sites was to include crop yield for all cash crops. For corn, a subsample of six corn plants per plot were to be taken for measuring mass of the plant components of grain, cob, and vegetative matter with $\mathrm{N}$ being analyzed on the grain and vegetative matter. Standard values for $\mathrm{C}$ for grain, cob, and vegetative matter and $\mathrm{N}$ for cob, were to be used along with the measured values to scale up to the plot area for $\mathrm{C}$ and $\mathrm{N}$ inputs and outputs. Corn plant stand was to be determined at the time of harvest. For sites studying cover crops, cover crop biomass was to be sampled in late fall if there was enough growth, and in spring before termination, and the cover crop tissues analyzed for $\mathrm{N}$ content.

Metadata. Metadata to be reported and included in the project database for agronomic management included such details as planting and harvest dates; plant populations; hybrid/variety; seeding rate; tillage implements, timing, and depth; residue management; fertilizer timing, rate, type, and application method; liming; and organic amendments. Pest management data to be reported and included are the occurrence and type of pest, applications of pesticides, and reasoning. In total, more than one hundred metadata types are possible, with only those applicable to a particular research site entered; therefore, only a subset of the total metadata options are completed per site.

The project proposal did not request funding for collection of basic weather variables (air temperature, humidity, solar radiation, wind, and precipitation) from the field sites, as most of the sites had preexisting sensors collecting many, if not all of these variables. The central database effort identified what sensors were currently deployed and will be centrally collecting this information. There are additional weather observations available from networks operated by the federal and state governments. The Iowa Environmental Mesonet (Herzmann et al. 2008) collects these observations and provides them on the website for download and use by this project. Additionally, this information is provided in a gridded format that allows the combination of datasets that have spatial and temporal holes. A benefit of this processing is a consistent long-term database of weather variables going back 30 or more years.

\section{Summary and Conclusions}

Changes in climate add a new layer of complexity to agricultural research. Large teams of scientists spanning across many different disciplines are needed to address the challenges of building a more resilient agriculture in the face of climate variations. As scientists come together in these large transdisciplinary teams, it is essential for members to actively participate in discussions across discipline boundaries, to learn a little about other disciplines, and to understand the reasons why various measurements are important. There is a learning curve for all involved with large team science, but the integration of physical, biological, and social sciences will likely lead to greater ability to improve agricultural systems in the future.

\section{Acknowledgements}

This research is part of a regional collaborative project supported by the USDA National Institute of Food and Agriculture (NIFA), Award No. 2011-68002-30190, Cropping Systems Coordinated Agricultural Project: Climate Change, Mitigation, and Adaptation in Corn-based Cropping Systems. The project website is sustainablecorn.org. The 11 institutions comprising the project team include the following land-grant universities: Iowa State University, Lincoln University, Michigan State University, The Ohio State University, Purdue University, South Dakota State University, University of Illinois, University of Minnesota, University of Missouri, University of Wisconsin, and the USDA Agricultural Research Service (ARS) in Columbus, Ohio. Research data and supporting metadata are stored in the team's centralized Climate and Cropping Systems database.

\section{References}

Blanco-Canqui, H., and A.J. Schlegel. 2013. Implications of inorganic fertilization of irrigated corn on soil 
properties: Lessons learned after 50 years. Journal of Environmental Quality 42:861-871.

Boone, R.D., D.F. Rigal, P. Sollins, R.J. Ahrens, and D.E. Armstrong. 1999. Soil sampling, preparation, archiving, and quality control. In Standard Soil Methods for LongTerm Ecological Research, eds. G.P. Robertson, D.C. Coleman, C.S. Bledsoe, and P. Sollins. New York, NY: Oxford University Press.

Bremner, J.M. 1996. Nitrogen-total. In Methods of Soil Analysis. Part 3,1085-1122. Chemical methods Agronomy Monograph 5. Madison, WI: American Society of Agronomy and Soil Science Society of America.

Dane, J.H., and J.W. Hopmans. 2002. Suction table. In Methods of Soil Analysis, Part 4, Physical Methods 692-697. Agronomy Monograph 5. Madison, WI: American Society of Agronomy and Soil Science Society of America.

Follett, R.F. 2010. Introduction. In GRACEnet Sampling Protocols, ed, R.F. Follett, 1-4. http://www.ars.usda. gov/research/GRACEnet.

Gee, G.W., and D. Or. 2002. Particle-size analysis. In Methods of Soil Analysis, Part 4, Physical methods, 255-294. Agronomy Monograph 5. Madison,WI:American Society of Agronomy and Soil Science Society of America.

Grossman, R.B., and T.G. Reinsch. 2002. Bulk density and linear extensibility. In Methods of Soil Analysis. Part 4, Physical methods, 201-228. Agronomy Monograph 5. Madison, WI: American Society of Agronomy and Soil Science Society of America.

Herzmann, D.E., J.Wolt, and R.Arritt. 2008. Representativity of a mesoscale network for weather-related factors governing pollen dispersal. International Journal of Biometeorology 52:617-624.

Herzmann, D.E., L.J. Abendroth, and L.D Bunderson. Data management approach to multidisciplinary agricultural research and syntheses. Journal of Soil and Water Conservation 69(6):180A-185A, doi:10.2489/ jswc.69.6.180A.

Hodgson, E.W., B.P. McCornack, K.A. Koch, D.W. Ragsdale, K.D. Johnson, M.E. O’Neal, E.M. Cullen, H.J. Kraiss, C.D. DiFonzo, and L.M. Behnken. 2007. Field validation of Speed Scouting for soybean aphid. Crop Management, doi:10.1094/CM-2007-0511-01-RS.

Iqbal, J., M.J. Castellano, and T.B. Parkin. 2012. Evaluation of photoacoustic infrared spectroscopy for simultaneous measurement of $\mathrm{N}_{2} \mathrm{O}$ and $\mathrm{CO}_{2}$ gas concentrations and fluxes at the soil surface. Global Change Biology. http://doi.wiley.com/10.1111/gcb.12021.

Islam K.R., and R.R. Weil. 2000. Soil quality indicator properties in mid-Atlantic soils as influenced by conservation management. Journal of Soil and Water Conservation 55:69-78.

Kladivko, E.J., G.E.Van Scoyoc, E.J. Monke, K.M. Oates, and W. Pask. 1991. Pesticides and nutrient movement into sub-surface tile drains on a silt loam soil in Indiana. Journal of Environmental Quality 20:264-270.
Kravchenko, A.N., and G.P. Robertson. 2011. Whole-Profile Soil Carbon Stocks:The Danger of Assuming Too Much from Analyses of Too Little. Soil Science Society of America Journal 75(1):235.

Lal, R. 1994. Methods and guideline for assessing sustainable use of soil and water resources. Soil Management Support Services Technical Monograph 21. Columbus, $\mathrm{OH}$ :The Ohio State University.

Lal, R. 2004. Soil carbon sequestration impacts on global climate change and food security. Science 304:1623-1627.

Lal, R. 2010. Beyond Copenhagen: Mitigating climate change and achieving food security through soil carbon sequestration. Food Security 2:169-177.

Lal, R., and R.F. Follett. 2009. Soil carbon sequestration and the greenhouse effect. Special publication 57, 2nd ed. Madison, WI: Soil Science Society of America.

Lal, R., M. Griffin, J. Apt, L. Lave, and M.G. Morgan. 2004. Managing soil carbon. Science 304:393.

Lal, R., J.M. Kimble, R.F. Follett, and C.V. Cole. 1998. The potential of U.S. cropland to sequester carbon and mitigate the greenhouse effect. Boca Raton, FL: CRC Press.

Linquist, B., K.J. van Groenigen, M.A. Adviento-Borbe, C. Pittelkow, and C. van Kessel. 2012. An agronomic assessment of greenhouse gas emissions from major cereal crops. Global Change Biology 18:194-209.

Lovett, G.M., J.J. Cole, and M.L. Pace. 2006. Is Net Ecosystem Production Equal to Ecosystem Carbon Accumulation? Ecosystems 9(1):152-155.

Lowery, B., and J.E. Morrison, Jr. 2002. Soil penetrometers and permeability. In Methods of Soil Analysis, part 4 Physical Methods, 363-384. Agronomy Monograph 5. Madison, WI: American Society of Agronomy and Soil Science Society of America.

McInnes, K.J. 2002. Temperature. In Methods of Soil Analysis. Agronomy, part 4 Physical methods, 1183-1189. Agronomy Monograph 5. Madison, WI: American Society of Agronomy and Soil Science Society of America.

Mulvaney, R.L. 1996. Nitrogen - inorganic forms. In Methods of Soil Analysis, part 3 Chemical methods, 1123-1184. Agronomy Monograph 5. Madison, WI: American Society of Agronomy and Soil Science Society of America.

Nelson, D.W., and L.E. Sommers. 1996. Total Carbon, Organic Carbon, and Organic Matter. In Methods of Soil Analysis, part 3, Chemical methods, 961-1010. Agronomy Monograph 5. Madison, WI: American Society of Agronomy and Soil Science Society of America.

Nimmo, J.R., and K.S. Perkins. 2002. Aggregate stability and size distribution. In Methods of Soil Analysis, part 4, Physical Methods, 317-328. Agronomy Monograph 5. Madison, WI: American Society of Agronomy and Soil Science Society of America.

Nutter, F.W. Jr., and D. Litwiller. 1998. A computer program to generate standard area diagrams to aid raters in assessing disease severity. Phytopathology 88:S117.
Parkin, T.B., and R.T. Venterea. 2010. Chamber-based trace gas flux measurements. In GRACEnet Sampling Protocols, ed, R.F. Follett, 1-39. http://www.ars.usda. gov/research/GRACEnet.

Reynolds, W.D., D.E. Elrick, and E.G. Youngs. 2002a. Ring or cylinder infiltrometers (vadose zone). In Methods of Soil Analysis, part 4, Physical methods, 818. Agronomy Monograph 5. Madison, WI: American Society of Agronomy and Soil Science Society of America.

Reynolds, W.D., D.E. Elrick, and E.G. Youngs. 2002b. Singlering and double- or concentric-ring Infiltrometers. In Methods of Soil Analysis, part 4, Physical methods, 821825. Agronomy Monograph 5. Madison, WI: American Society of Agronomy and Soil Science Society of America.

Robertson, G.P., E.A. Paul, and R.R. Harwood. 2000. Greenhouse gases in intensive agriculture: contribtions of individual gases to the radiative forcing of the atmosphere. Science 289:1922-1925.

Rolston, D.E., and P. Moldrup. 2002. Gas diffusivity. In Methods of Soil Analysis, part 4, Physical methods, 1113-1137. Agronomy Monograph 5. Madison, WI: American Society of Agronomy and Soil Science Society of America.

Shuster, W.D., M.J. Shipalto, P.J. Bohlen, S. Subler, and C.A. Edwards. 2003. Population dynamics of ambient and altered earthworm communities in row-crop agroecosystems in the midwestern U.S. Pedobiologia. 47:825-829.

Sumner, M.E., and W.P. Miller. 1996. Cation exchange capacity and exchange coefficients. In Methods of Soil Analysis, part 3, Chemical methods, 1201-1230. Agronomy Monograph 5. Madison, WI: American Society of Agronomy and Soil Science Society of America.

Swift, R.S. 1996. Organic matter characterization. In Methods of Soil Analysis, part 3. Chemical methods, 1011-1070. Agronomy Monograph 5. Madison, WI: American Society of Agronomy and Soil Science Society of America.

Thomas, G. 1996. Soil pH and soil acidity. In Methods of Soil Analysis, part 3, Chemical methods, 475-490. Agronomy Monograph 5. Madison, WI: American Society of Agronomy and Soil Science Society of America.

Topp, G.C., and P.A. Ferré. 2002. General Information. In Methods of Soil Analysis, part 4, physical methods, 417-418. Agronomy Monograph 5. Madison, WI:American Society of Agronomy and Soil Science Society of America. 